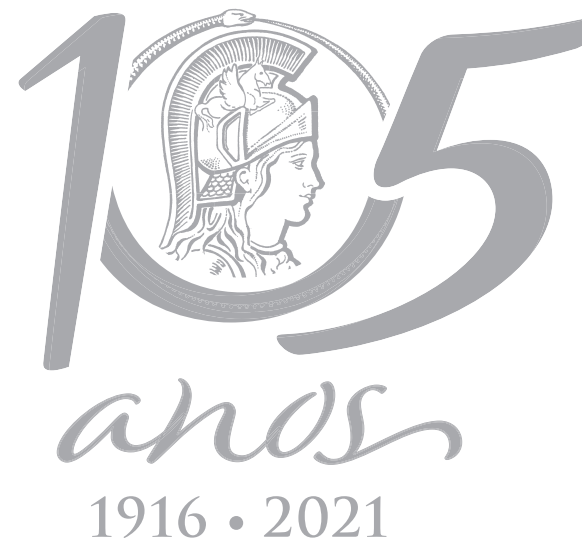

$1916 \cdot 2021$

\title{
ECOSYSTEMS
}

\section{A new report of phytomelanin in cypselae of Vernonieae: the case of the type species of Lychnophora Mart.}

\author{
DANILO MARQUES, JULIANA MARZINEK \& ORLANDO C. DE-PAULA
}

\begin{abstract}
Phytomelanin is a mechanically hard, blackish, and inert substance rarely found in plants. In Asteraceae, this substance was historically associated with the Heliantheae alliance, but recent studies have observed it in unrelated groups as Heterocoma and Wunderlichia. During a taxonomic investigation, we found phytomelanin in cypselae of Lychnophora salicifolia an unusual feature in Vernonieae previously found only in Heterocoma. Furthermore, phytomelanin fills the intercellular spaces of the sclerenchymatic outer mesocarp in L. salicifolia. Our results doubt the (syn)apomorphy status in Heterocoma, suggest the phytomelanin may have not the same evolutionary significance in Lychnophorinae as in other tribes and proposes new perspectives for evolutionary studies in Asteraceae.
\end{abstract}

Key words: Compositae, calcium oxalate crystals, fruit anatomy, Lychnophorinae, micromorphology.

\section{INTRODUCTION}

Cypselae are typical fruits found in Asteraceae (Marzinek et al. 2008), with high taxonomic value at different hierarchical levels (Marzinek et al. 2010, Marzinek \& Oliveira 2010, Pandey et al. 2014, Tadesse \& Crawford 2014, Franca et al. 2015, Silva et al. 2018, Bonifácio et al. 2019). One of the most notable features of the cypselae is phytomelanin, a brown to black non-cellular layer, hard, and resistant to degradation (Stuessy \& Liu 1983), classically associated with the Heliantheae alliance pericarp (Misra 1964, 1972, Pullaiah 1979, 1981, Pandey \& Singh 1982, 1983, 1994, Stuessy \& Liu 1983, Pandey et al. 1989, Pandey 1998, Pandey \& Dhakal 2001, Baldwin 2009). However, recent studies have reported unrelated groups (Freitas et al. 2015, Bonifácio et al. 2019), suggesting that phytomelanin is underestimated (De-Paula et al. 2013). From its earliest reports (Hanausek 1902, 1907, 1912) to the present day (i.e., De-Paula et al. 2013, Pandey et al. 2014, Tadesse \& Crawford 2014, Franca et al. 2015, Freitas et al. 2015, Lusa et al. 2018, Silva et al. 2018, Bonifácio et al. 2019, Mathur \& Pandey 2020), Synantherologists have been questioning the evolutionary significance of phytomelanin in Asteraceae fruits.

During taxonomic studies on Brazilian Vernonieae, we observed cypselae in Lychnophora type species were black due to the phytomelanin as in Heterocoma. As both genera are circumscribed in Lychnophorinae (Loeuille et al. 2015) and have cypselae with phytomelanin, we evaluated its deposition pattern in Lychnophora salicifolia Mart. and compared it with Heterocoma species, reassessing the systematics significance of the phytomelanin in Lychnophorinae and Asteraceae fruit evolution. 


\section{MATERIALS AND METHODS}

We analyzed the cypselae of nine specimens of Lychnophora salicifolia (Table I). For the morphological study, cypselae were mounted on aluminum stubs and coated with gold using a sputter coater (Leica EM SCD050). The cypselae were observed using scanning electron microscopy (Zeiss EVO MA 100), and the images were digitally acquired.

For the anatomical study, cypselae were rehydrated in a $5 \mathrm{~N} \mathrm{NaOH}$ solution for four hours (Anderson 1963, modified), dehydrated in an ethanol series, and embedded in historesin following the manufacturer's protocol (Leica Microsystems). The cypselae were sectioned at $10 \mu \mathrm{m}$ thickness using a rotary microtome (Leica RM 2235) and stained with $0.05 \%$ toluidine blue (O'Brien et al. 1964, modified). The sections were mounted in synthetic resin (Entellan), observed under a light microscope (Olympus BX51 with DP70 digital camera attached) and the images were also digitally acquired. The results were described following Roth (1977), wherein the exocarp originates from the ovarian inner epidermis, the endocarp from the inner epidermis, and the mesocarp from fundamental and vascular tissues. The endocarp and the innermost layers of the parenchymatic mesocarp are commonly crushed and consumed by seed growth.

\section{RESULTS}

\section{Morphology}

All specimens analyzed have cylindrical cypselae with well-developed ribs (Figure 1a) and twin hairs (zwillingshaare) among them. The carpopodium is conspicuous and symmetrical. The pappus is biseriate with a paleaceous and persistent outer series and a caducous inner series.

\section{Anatomy}

The pericarp of $L$. salicifolia possesses a uniseriate exocarp, and the mesocarp is divided into two regions, both with several layers. The outer mesocarp is composed of lignified cells (sclerenchyma) with phytomelanin filling its

Table I. List of Lychnophora salicifolia specimens examined.

\begin{tabular}{|c|c|}
\hline \multicolumn{1}{|c|}{ Locality } & Voucher information \\
\hline $\begin{array}{c}\text { Brazil, Brasilia, Norte de Brazlândia } \\
\text { Brazil, Brasília, Alto Paraíso de Goiás, Parque Nacional } \\
\text { Chapada dos Veadeiros }\end{array}$ & R.F. Vieira 2613 (HUFU) \\
\hline $\begin{array}{c}\text { Brazil, Minas Gerais, Parque Nacional Chapada dos Veadeiros, } \\
\text { trilha para Mulungu no parque }\end{array}$ & A.A.A. Barbosa et al. 169 (HUFU) \\
\hline Brazil, Minas Gerais, Rio Pardo de Minas & A.C. Sevilha et al. 4342 (HUFU) \\
\hline Brazil, Minas Gerais, Parque Estadual do Rio Preto & D.A. Chaves 375 (HUFU) \\
\hline Brazil, Minas Gerais, Serra do Cipó & H.C. Sousa S.n. (HUFU 56703) \\
\hline Brazil, Minas Gerais, Serra do Cipó & H.C. Sousa S.n. (HUFU 56704) \\
\hline Brazil, Minas Gerais, Serra do Cipó & H.C. Sousa S.n. (HUFU 56706) \\
\hline Brazil, Minas Gerais, Serra do Cipó & H.C. Sousa s.n. (HUFU 58732) \\
\hline
\end{tabular}



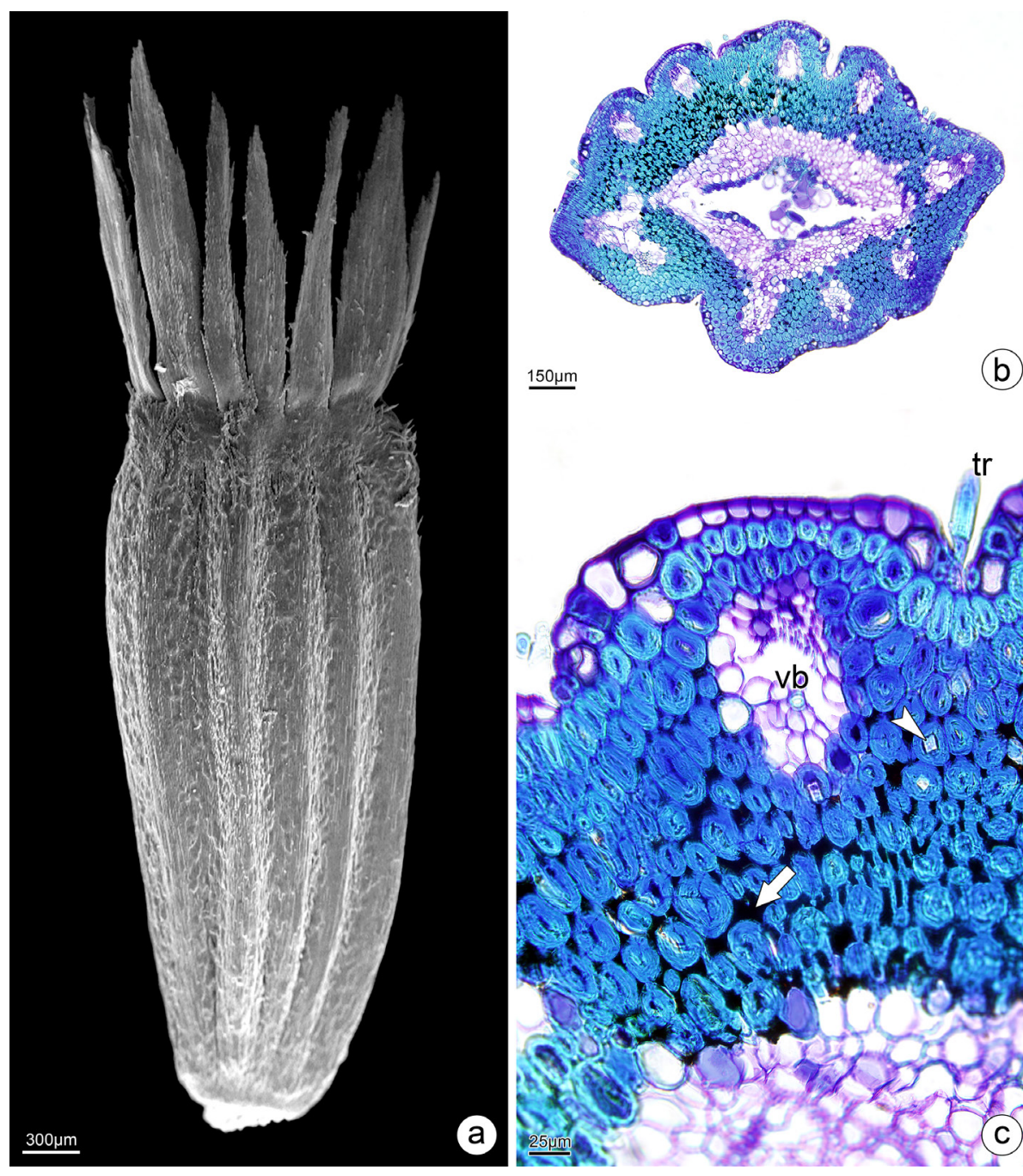

(b)

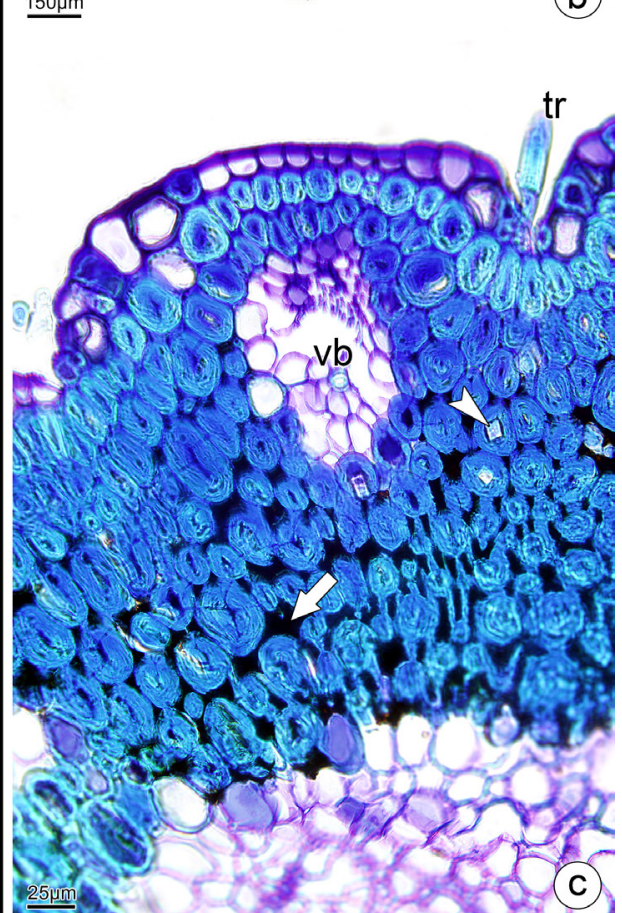

Figure 1. Cypselae morphology of Lychnophora salicifolia. arrow= phytomelanin; arrowhead= calcium oxalate crystal; tr= trichome; $v b=$ vascular bundle. (a) General view (SEM), (b-c) transversal sections, (b) general view, (c) detail of the pericarp showing the phytomelanin and some crystals. intercellular spaces. The inner mesocarp is parenchymatic and partially consumed by the seed development, which also absorbs the endocarp. Calcium oxalate crystals were observed in the outer mesocarp cells (Figure $1 b-c)$.

\section{DISCUSSION}

The cypsela of L. salicifolia was similar to Heterocoma species, differing by indument, pappus, and mesocarp. Externally, the cypsela of $L$. salicifolia possesses twin hairs among the ribs, while Heterocoma is glabrous (Freitas et al. 2015). Regarding the pappus, the outer series of L. salicifolia is conspicuous and reduced in most species of Heterocoma, except $H$. albida (Freitas et al. 2015). Internally, the pericarp of Lychnophora salicifolia differs from Heterocoma by possessing calcium oxalate crystals in the mesocarp. The two most significant novelties of $L$. salicifolia were the occurrence of phytomelanin and the latter with calcium oxalate crystals simultaneously. Robinson (2009) noted that cypselae with phytomelanin never contain crystals, resulting from calcium oxalate crystals can be antagonistic to the phytomelanin production (King \& Robinson 1987) or used in its production/secretion. This can be seen in the Heliantheae alliance; for example, the 
Helenieae is the only tribe that does not have phytomelanin and possesses crystals (Baldwin 2009). Nevertheless, this is the first report of the phytomelanin and crystals occurrence in the pericarp of Asteraceae concomitantly.

The phytomelanin was previously reported in stems of L. salicifolia by Lusa et al. (2018) when studied the evolutionary implication of phytomelanin in shoots of Lychnophorinae species. The reconstruction of ancestral character states indicated the most recent common ancestor of Lychnophorinae probably had phytomelanin in a thickened stem. However, the occurrence of phytomelanin in young stems and leaves would have appeared later, occurring independently in various taxa throughout the evolution of the group (Lusa et al. 2018). Also in Lychnophorinae, the phytomelanin in the stems could indicate that this pigment appeared first in the stem and was later incorporated into fruits (Lusa et al. 2018). This fact, along with the other phytomelanin distribution patterns among cypselae of Asteraceae studied until now, supports the hypothesis that fibers are responsible for the secretion of phytomelanin, as hypothesized by De-Paula et al. (2013).

The phytomelanin deposition pattern has presented a higher systematic value than only its occurrence. Freitas et al. (2015) reviewed the structure of fruits with phytomelanin and found three patterns distributing the Asteraceae pigment. The Eupatorieae pattern, in which there is a separation between the outer (parenchymatic) and inner (lignified) mesocarp, generates a schizogenous space filled by phytomelanin (Pandey \& Singh 1983, 1994, Marzinek \& Oliveira 2010, De-Paula et al. 2013, Freitas et al. 2015). In the Heliantheae pattern, no tissue separation and secretion occurs between the inner (parenchymatous) and internal (lignified) cells of the mesocarp (Misra 1964, 1972, Pandey \& Singh 1982, 1994, Stuessy
\& Liu 1983, Pandey 1998, Julio \& Oliveira 2009, Frangiote-Pallone \& Souza 2014, Pandey et al. 2014, Freitas et al. 2015, Mathur \& Pandey 2020). In the Heterocoma pattern, the phytomelanin occurs between the outer (lignified) and inner (parenchymatous) mesocarp (Freitas et al. 2015). Posteriorly, a different pattern was found by Bonifácio et al. (2019) in species of the genus Wunderlichia (Wunderlichieae, Asteraceae). In this pattern, phytomelanin is secreted between exocarp and mesocarp and around the phloem fibers. The phytomelanin secretion patterns are conservative in all the taxa studied until now (Freitas et al. 2015, Bonifacio et al. 2019). Both L. salicifolia and Heterocoma share a common pattern, and both are members of the subtribe Lychnophorinae. These patterns are relevant to studies with an evolutionary approach since they indicate homoplasy in the subtribe since, at the generic level, Heterocoma and Lychnophora are thought to lack a common ancestor (Loeuille et al. 2015).

\section{CONCLUSIONS AND PERSPECTIVES}

Despite the increasing number of phylogenetic studies, morphological and anatomical data are still essential for understanding the Asteraceae lineages. For many years, phytomelanin has been considered a (syn)apomorphy to the Heliantheae alliance, the latest divergent Asteraceae group (Panero \& Funk 2008). However, recent anatomical studies (Fritz \& Saukel 2011, Pandey et al. 2014, Freitas et al. 2015, Lusa et al. 2018, Bonifácio et al. 2019, Mathur \& Pandey 2020, this study) have shown that the phytomelanin in this family is more widely distributed. Our results reinforce the idea that phytomelanin is homoplastic in Asteraceae and raises doubts about how conserved it may be the phytomelanin deposition pattern found in 
Lychnophorinae. Consequently, a more extensive study should be conducted to evaluate the importance of cypselae in the systematics and evolution of this subtribe.

\section{Acknowledgments}

The authors thank the Laboratório Multiusuário de Microscopia Eletrônica of the Faculdade de Engenharia Química (UFU) for SEM facilities. The first author to thank the Conselho Nacional de Desenvolvimento Científico e Tecnológico (CNPq, Proc. 301734/2020-8) and Fundação Cearense de Apoio ao Desenvolvimento Científico e Tecnológico (Funcap Proc. DC8-0145-00117.01.00/18 and 9973919/2018) for the scholarship granted. The authors declare no conflicts of interest.

\section{REFERENCES}

ANDERSON LC. 1963. Studies on Petradoria (Compositae): anatomy, cytology, taxonomy. Trans Kans Acad Sci 66: 632-684.

BALDWIN BG. 2009. Heliantheae alliance. In: Funk V, Susanna A, Stuessy T \& Bayer A (Eds), Systematics, evolution and biogeography of Compositae, Vienna, IAPT, p. 689-711.

BONIFÁCIO SKV, MOURA LL, MARZINEK I \& DE-PAULA OC. 2019. Comparative embryology of Stifftia and Wunderlichia and implications for its evolution in Asteraceae. Bot J Linn Soc 189: 169-185.

DE-PAULA OC, MARZINEK J, OLIVEIRA DMT \& MACHADO SMR. 2013. The role of fibers and the hypodermis in Compositae melanin secretion. Micron 44: 312-316.

FRANCA RO, DE-PAULA OC, CARMO-OLIVEIRA R \& MARZINEK J. 2015. Embryology of Ageratum conyzoides L. and A. fastigiatum R. M. King \& H. Rob. (Asteraceae). Acta Bot Bras 29: 8-15.

FRANGIOTE-PALLONE S \& SOUZA LA. 2014. Ontogenia del papus y cipsela en Asteraceae: las consideraciones structurales de la categoría tribal. Rev Mex Biodivers 85: 62-77.

FREITAS FS, DE-PAULA OC, NAKAJIMA JN \& MARZINEK J. 2015. Fruits of Heterocoma (Vernonieae-Lychnophorinae): taxonomic significance and a new pattern of phytomelanin deposition in Asteraceae. Bot J Linn Soc 179: 255-265.
FRITZ E \& SAUKEL J. 2011. Secretory structures of subterranean organs of some species of the Cardueae, and their diagnostic value. Acta Biol Cracov Bot 53: 62-72.

HANAUSEK TF. 1902. Zur Entwicklungsgeschicte des Perikarps von Helianthus annuus. Ber Deut Bot Ges 20: 449-454.

HANAUSEK TF. 1907. Die "Kohleschicht" im Perikarp der Kompositen. Sitzungsber Kaiserl Akad Wiss, Math.Naturwiss. Kl. 1116: 3-32.

HANAUSEK TF. 1912. Untersuchungen uber die kohleahnliche Masse der Kompositen. Denkschr - terr Akad Wiss Math.-Naturwiss. Kl. 87: 93-142.

JULIO PGS \& OLIVEIRA DMT. 2009. Morfoanatomia comparada e ontogênese do pericarpo de Bidens gardneri Baker e B. pilosa L. (Asteraceae). Rev Bras Bot 32: 109-116.

KING RM \& ROBINSON H. 1987. The genera of the Eupatorieae (Asteraceae). Monographs in Systematic Botany from the Missouri Botanical Garden 22. Allen Press, Inc., Kansas: Lawrence, 581 p.

LOEUILLE BFP, SEMIR J, LOHMANN LG \& PIRANI JR. 2015. A phylogenetic analysis of Lychnophorinae (Asteraceae: Vernonieae) based on molecular and morphological data. Syst Bot 40: 299-315.

LUSA MG, LOEUILLE BFP \& APEZZATO-DA-GLÓRIA B. 2018. First record of phytomelanin in aerial vegetative organs and its evolutionary implications in Lychnophorinae (Vernonieae: Asteraceae). Perspect Plant Ecol Evol Syst 33: $18-33$

MARZINEK J, DE-PAULA OC \& OLIVEIRA DMT. 2008. Cypsela or achene? Refining terminology by considering anatomical and historical factors. Braz J Bot 31: 549-553.

MARZINEK J, DE-PAULA OC \& OLIVEIRA DMT. 2010. The ribs of Eupatorieae (Asteraceae): of wide taxonomic value or reliable characters only among certain groups? Plant Syst Evol 285: 127-130.

MARZINEK I \& OLIVEIRA DMT. 2010. Structure and ontogeny of the pericarp of six Eupatorieae (Asteraceae) with ecological and taxonomic considerations. An Acad Bras Cienc 82: 279-291.

MISRAS. 1964. Floral morphology of the family Compositae. 2. Development of the seed and fruit in Flaveria repanda. Bot Mag Tokyo 77: 290-296.

MISRA S. 1972. Floral morphology of the family Compositae. IV. Tribe Vernonieae - Vernonia anthelmintica. Bot Mag Tokyo 85: 187-199. 
MATHUR RR \& PANDEY AK. 2020. Development and structure of phytomelanin in Coreopsieae (Asteraceae). Int J Plt Repro Biol 12: 84-94.

O'BRIEN TP, FEDER N \& MCCUlly ME. 1964. Polychromatic staining of plant cell walls by toluidine blue 0 . Protoplasma 59: 368-373.

PANDEY AK. 1998. Development of phytomelanin layer in fruit wall of Tagetes patula L. (Asteraceae). J Indian Bot Soc 77: 35-38.

PANDEY AK \& DHAKAL MR. 2001. Phytomelanin in Compositae. Curr Sci 80: 933-940.

PANDEY AK, LEE WW, SACK FD \& STUESSY TF. 1989. Development of the phytomelanin layer in fruits of Ageratum conyzoides (Compositae). Am J Bot 75: 739-746.

PANDEY AK \& SINGH RP. 1982. Development and structure of seeds and fruits in the Compositae, tribe Senecioneae. Bot Jahrb Syst Pflanzengesch Pflanzengeogr 103: 413-422.

PANDEY AK \& SINGH RP. 1983. Development and structure of seeds and fruits in Compositae: tribe Eupatorieae. J Indian Bot Soc 62: 276-281.

PANDEY AK \& SINGH RP. 1994. Development and structure of seed and fruit in Eupatorieae and Heliantheae (Compositae). Proc Natl Acad Sci India 64: 115-126.

PANDEY AK, STUESSY TF \& MATHUR RR. 2014. Phytomelanin and systematics of the Heliantheae alliance (Compositae). Plant Divers Evol 131: 1-21.

PANERO JL \& FUNK VA. 2008. The value of sampling anomalous taxa in phylogenetic studies: major clades of Asteraceae revealed. Mol Phylogenet Evol 47: 757-782.

PULLAIAH T. 1979 Embryology of Adenostemma, Elephantopus and Vernonia (Compositae). Bot Not 132: 51-56.

PULLAIAH T. 1981. Studies in the Embryology of Heliantheae (Compositae). Plant Syst Evol 137: 203-213.

ROBINSON H. 2009. An introduction to micro-characters of Compositae. In: Funk V, Susanna A, Stuessy T \& Bayer A (Eds), Systematics, evolution and biogeography of Compositae, Vienna, IAPT, p. 89-100.

ROTH I. 1977. Fruits of angiosperms. Berlin: Gebrüder Borntraeger, $675 \mathrm{p}$.

SILVA TDG, MARZINEK J, HATTORI EKO, NAKAJIMA JN \& DEPAULA OC. 2018. Comparative cypsela morphology in Disynaphiinae and implications for their systematics and evolution (Eupatorieae: Asteraceae). Bot J Linn Soc 186: 89-107.
STUESSY TF \& LIU H. 1983. Anatomy of the pericarp of Clibadium, Desmanthodium and Ichthyothere (Compositae, Heliantheae) and systematics implications. Rhodora 85: 213-227.

TADESSE M \& CRAWFORD DJ. 2014. The phytomelanin layer in traditional members of Bidens and Coreopsis and phylogeny of the Coreopsideae (Compositae). Nord J Bot 32: 80-91.

\section{How to cite}

MARQUES D, MARZINEK J \& DE-PAULA OC. 2021. A new report of phytomelanin in cypselae of Vernonieae: the case of the type species of Lychnophora Mart. An Acad Bras Cienc 93: e20210204. DOI 10.1590/00013765202120210204.

Manuscript received on February 12, 2021;

accepted for publication on July 4, 2021

\section{DANILO MARQUES}

https://orcid.org/0000-0003-2571-9874

\section{JULIANA MARZINEK ${ }^{2}$}

https://orcid.org/0000-0002-4482-0655

\section{ORLANDO C. DE-PAULA ${ }^{2}$}

https://orcid.org/0000-0002-8089-2082

${ }^{1}$ Universidade Federal do Ceará, Programa de Pós-Graduação em Sistemática, Uso e Conservação da Biodiversidade, Departamento de Biologia, Campus do Pici, Avenida Mister Hull, s/n, 60440-900 Fortaleza, CE, Brazil

${ }^{2}$ Universidade Federal de Uberlândia, Instituto de Biologia, Rua Ceará, s/n, 38405-315 Uberlândia, MG, Brazil

Correspondence to: Orlando Cavalari De-Paula

E-mail: ocavalari@ufu.br

\section{Author contributions}

All authors contributed to the idea's conception, analysis and discussion of results, preparation of images, bibliographic research, revision, and manuscript editing.

\section{(cc) BY}

